\title{
Data report: diatom and silicoflagellate records of marine isotope Stages 25-27 at IODP Site U1387, Faro Drift ${ }^{1}$
}

\author{
Cristina Ventura, ${ }^{2,}{ }^{3}$ Fatima Abrantes, ${ }^{2,}{ }^{3}, 4$ Isabel Loureiro, ${ }^{2}$ and Antje H.L. Voelker ${ }^{2,} 4$
}

\section{Chapter contents}

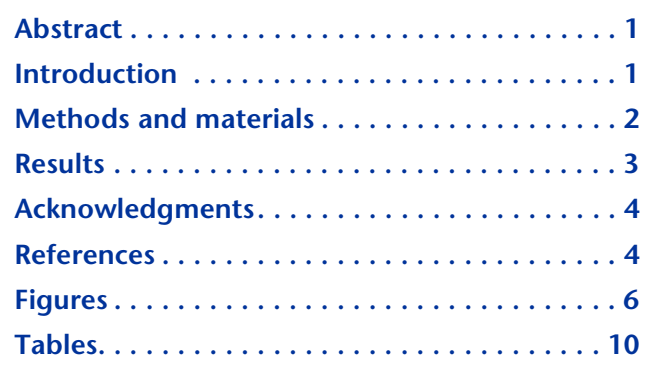

1Ventura, C., Abrantes, F., Loureiro, I., and Voelker, A.H.L., 2017. Data report: diatom and silicoflagellate records of marine isotope Stages 25-27 at IODP Site U1387, Faro Drift. In Stow, D.A.V., Hernández-Molina, F.J., Alvarez Zarikian, C.A., and the Expedition 339 Scientists, Proceedings of the Integrated Ocean Drilling Program, 339: Tokyo (Integrated Ocean Drilling Program Management International, Inc.). doi:10.2204/iodp.proc.339.202.2017 2Divisão de Geologia e Georecursos Marinhos, Instituto Português do Mar e da Atmosfera (IPMA), Rua Alfredo Magalhães Ramalho 6, 1495-006 Lisboa, Portugal. Correspondence author: antje.voelker@ipma.pt ${ }^{3}$ CIIMAR, Universidade do Porto, Rua dos Bragas 287, 4050-123 Porto, Portugal.

${ }^{4}$ CCMAR, Centro de Ciencias do Mar, Universidade do Algarve, Campus de Gambelas, 8005-139 Faro, Portugal.

\section{Abstract}

During Integrated Ocean Drilling Program Expedition 339, the shipboard micropaleontological studies of Site U1387 core catcher samples revealed the preservation of diatoms and radiolarians in specific depths from early Pleistocene age (900-1000 ka). To evaluate the ecological significance of those diatoms, we analyzed 98 samples from the intervals of 244 to $274 \mathrm{~m}$ along the corrected splice, corresponding to marine isotope Stage (MIS) 25 to MIS 29, for the abundance of diatoms and silicoflagellates. In 6 samples, the composition of the diatom assemblage was determined as well. Although most samples were barren of siliceous microfossils, the downcore record revealed two intervals, 249-252 corrected meters composite depth (cmcd) and 263-265 cmcd, where diatoms and silicoflagellates reach their maximum values. These maxima occurred from the MIS 26/25 transition to interglacial MIS 25, and again during early MIS 27 . The diatom assemblage includes 27 identified taxa with Chaetoceros (Hyalochaete) resting spores being dominant and Thalassionema nitzschioides and Paralia sulcata significant. The Chaetoceros spores clearly indicate strong influence of seasonal upwelling and associated high primary productivity. Special to the diatom record is, however, the occurrence of the large-diameter $(>125 \mu \mathrm{m})$ centric diatoms Coscinodiscus asteromphalus, Coscinodiscus apiculatus, and Coscinodiscus cf. gigas that imply incursions of low-nutrient, open-ocean water into the southern Portuguese coast during MIS 25.

\section{Introduction}

Diatoms are unicellular algae that segregate into opaline silica frustules with two valves and constitute one of the major players in the basis of the trophic chain. Planktonic and benthic forms exist in both freshwater and marine environments and reflect the environmental conditions in such settings, making these organisms excellent indicators for past environments. In the modern ocean, diatoms are abundant in sediments underlying temperate continental shelves, where nutrient and photic conditions in the upper mixed oceanic layer are seasonally favorable for them to quickly divide and dominate the phytoplankton communities (the "spring bloom") and in upwelling regions where nutrient input can be seasonal or perennial (coastal, equatorial, and high-latitude regions). Contrary to the small r-strategic species that domi- 
nate in those regions, in the open ocean, where conditions are typically oligotrophic, diatoms tend to be larger and in some cases capable of actively regulating their buoyancy to counter sinking rates (Dugdale and Wilkerson, 1998). However, openocean diatoms might also become very abundant through concentration along frontal regions or thermal wave instabilities (Yoder et al., 1994), which are recorded in the sediments as diatom mats (Kemp, 1995; Smetacek, 2000; Kemp et al., 2006).

The standard shipboard micropaleontological evaluation of the sites recovered during Integrated Ocean Drilling Program Expedition 339, Mediterranean Outflow (see the "Site U1387" chapter [Expedition 339 Scientists, 2013]), revealed the presence of diatoms (some pyritized) and radiolarians in core catcher samples from Site U1387 $\left(36.8^{\circ} \mathrm{N}, 7.7^{\circ} \mathrm{W} ; 559\right.$ $\mathrm{m}$ below sea level; Fig. F1), especially in Sample 339U1387B-24X-CC. As a follow up, we investigated the total abundance (valves/gram) and diatom assemblage composition, as well as the presence of other siliceous microfossils in samples surrounding this level, in order to evaluate its ecological meaning.

Site U1387 is under the direct influence of the upper core of Mediterranean Outflow Water (MOW) (see the "Site U1387" chapter [Expedition 339 Scientists, 2013]); Voelker et al., 2015), and surface waters of subtropical origin are transported by the eastern branch of the Azores Current (far offshore) and the eastbound Gulf of Cadiz Slope Current (GCC), an open-ocean current located along the southern Iberian margin (Peliz et al., 2009) (Fig. F1). During the upwelling season (May-September), the filament formed off Cape São Vicente frequently extends eastward along the southern shelf break and slope of Portugal (Relvas and Barton, 2002), potentially influencing Site U1387. In addition, a local upwelling plume can form off Cape Santa Maria (Fig. F1) under westerly winds (Criado-Aldeanueva et al., 2006; Navarro and Ruiz, 2006).

\section{Methods and materials}

Diatom and other siliceous microfossil abundance was analyzed on 98 samples of Cores 339-U1387B24X through 26X and 339-U1387A-25X and 26X (Table T1) following the corrected composite depth of the new splice for the early to Middle Pleistocene section at Site U1387 (Voelker et al., unpubl. data).

For diatom quantification, sediments were cleaned and mounted according to the method described by Abrantes et al. (2005). Diatom counting (centric, pennate, freshwater, benthic, Chaetoceros resting spores, and fragments) was undertaken according to the unit definitions by Schrader and Gersonde
(1978) at $1000 \times$ magnification using a Nikon microscope with differential interference contrast illumination.

Quantitative abundance estimation is based on the median value obtained from counts of 100 random fields of view on 3 replicate slides for each sample. With this counting method, and knowing the area of the microscope field of view (FOV), the absolute number of diatom valves per gram of sediment can be calculated as

$$
\text { Valves } / g=[(N \times(\mathrm{S} / \mathrm{s})] \times(\mathrm{V} / \mathrm{v}) / \mathrm{W},
$$

where

$$
\begin{aligned}
& N= \text { median number in } 100 \mathrm{FOV} \text { and } 3 \text { replicate } \\
& \text { slides } \\
& \mathrm{S}= \text { area of the evaporation tray, } \\
& \mathrm{S}= \text { area of slide covered for counting, } \\
& \mathrm{V}=\text { total solution, } \\
& \mathrm{V}=\text { solution volume extracted to dry, and } \\
& \mathrm{W}=\text { weight of the treated, dried raw sample. }
\end{aligned}
$$

Absolute diatom numbers are presented as number of valves per gram of sediment and silicoflagellates as number of specimens per gram of sediment. Analysis of replicate slides reduce the analytical error on the estimate of absolute abundances to $\leq 10 \%$ of measured values.

Assemblage composition was determined for 8 samples selected on the basis of total diatom abundance (Fig. F2C). Percent abundance is calculated from the identification of 300 specimens, but in cases where total diatom abundance fell below $10^{6}$ valves/g, the number of specimens counted was reduced to 100 (Fatela and Taborda, 2002).

Diatom identification followed the descriptions of Hustedt (1964), Hasle (1977), Carmelo (1996), and Round et al. (2007), and a list of the 27 identified taxa is presented in Table T2. The dominant taxa were considered independently as well as grouped according to their ecological preferences (e.g., benthic, freshwater, marine). Within the marine grouping we also split the pelagic forms into cold- and warm-water groups (Hustedt, 1964; Hasle, 1977; Carmelo, 1996). Groups that comprise $<2 \%$ of the total diatom assemblage were discarded from further analyses.

As pointed out by Voelker et al. (2015), the shipboard splice of Site U1387 is incomplete within the middle to early Pleistocene section. The higher resolution X-ray fluorescence (XRF) and foraminiferal shell stable isotope records were therefore used to revise the splice resulting in a corrected meters composite depth (cmcd) scale. The current study encompasses samples from 244 to 274 cmcd ( 236-260 
mcd) and the splice corrections within this interval include

1. Appending the top of Section 339-U1387A-25X1 to the bottom of Section 339-U1387B-24XCC;

2. Incorporating $2.94 \mathrm{~m}$ into the splice for a transition from Section 339-U1387B-25X-6, $125 \mathrm{~cm}$, to 339-U1387A-26X-1, $5 \mathrm{~cm}$; and

3. Adding $0.96 \mathrm{~m}$ at the subsequent splice transition for a shift from Section 339-U1387A-26X-4, $113 \mathrm{~cm}$, to $339-\mathrm{U} 1387 \mathrm{~B}-26 \mathrm{X}-1,78 \mathrm{~cm}$.

Samples of Core 339-U1387B-24X themselves already inherited additional $8.53 \mathrm{~m}$ to their mcd values (from splice corrections above).

The stratigraphy of the studied interval is based on the $\delta^{18} \mathrm{O}$ record of the planktonic foraminifer Globigerina bulloides (Fig. F2A).

\section{Results}

\section{Diatom and silicoflagellate abundances}

The total abundance of diatoms and silicoflagellates is presented in Figure F2. Although most of the studied interval is barren of both siliceous microfossils, they co-occur with abundances that are on the same order of magnitude $\left(10^{6}\right)$ as encountered in surface (approximately modern) sediments of the Portuguese margin (Abrantes, 1988) in two specific intervals, 249-252 and 263-265 cmcd (e.g., from the MIS 26/MIS 25 transition to the middle of the interglacial period of MIS 25 and, again during early MIS 27 (middle of MIS 27c) (Fig. F2).

High diatom abundance in the sediments is a good indicator of increased primary production in the surface waters. However, given that several environmental conditions can lead to increased production, it is important to evaluate the assemblage's composition. Figure F3 shows the contribution of the different species/groups to the total assemblage in 6 of the 8 samples containing a sufficient number $(\geq 95)$ of diatoms. Resting spores of the genus Chaetoceros dominate the assemblage (45\%-65\%) at all levels, although their highest abundance occurs at 252.00 cmcd, which according to the isotopic stratigraphy corresponds with MIS 26/25 transition. Other significant contributors to the assemblage are Thalassionema nitzschioides and Paralia sulcata, with T. nitzschioides being important at the interglacial MIS 25 maximum and $P$. sulcata at the early MIS 27 maximum. Large (>125 $\mu \mathrm{m})$ Coscinodiscus, mainly Coscinodiscus asteromphalus (Fig. F4A) and few Coscinodiscus apiculatus and Coscinodiscus cf. gigas (Fig. F4B), were observed at two levels (249.68 and $249.91 \mathrm{cmcd}$ ) during the MIS 25 interglacial period and in the shipboard core catcher sample of Core 339-U1387B24X. Although abundant at both levels, higher numbers were observed at 249.91 cmcd in Sample 339U1387B-24X-5, 124.5-126.5 cm, in which specimens $>63 \mu \mathrm{m}$ but $<125 \mu \mathrm{m}$ were also common but were mostly pyritized.

In respect to ecologic groups, the cold-water pelagic forms never contribute $>4 \%$ and the warm-water pelagic forms have higher contribution during early MIS 27 (Fig. F3A). The low abundance of benthic forms $(<2 \%)$ is an important indication that the downcore diatom signal is likely to be a record of local oceanographic conditions rather than the result of downslope transport from shallower depths $(<200$ $\mathrm{m})$ caused either by bottom currents or sedimentological processes, although the identified forms are relatively resistant to dissolution (Fig. F3B).

All three important components of the diatom assemblage (Chaetoceros resting spore, $T$. nitzschioides, and $P$. sulcata) are common in the shelf and upper slope sediments of coastal upwelling regions. On the Portuguese coast, species of the Chaetoceros genus are mostly important during the seasonal upwelling period, and the highest abundance of their resting spores in the sediments mark the inner upwelling front (Abrantes, 1988; Abrantes and Moita, 1999; Moita, 2001). T. nitzschioides is a species commonly found in and around productive coastal upwelling regions in particular off Peru (de Mendiola, 1981) and in the Atlantic and equatorial Pacific (Hasle, 1959). On the Portuguese margin, it is present in the water column throughout the year and is homogeneously distributed in the Portuguese shelf sediments. $P$. sulcata is rare in the water column where it appears in near-coast upwelling centers but is common in the shelf sediments.

Notable to this record is the presence of Coscinodiscus asteromphalus, a large-diameter species (Fig. F4A) associated with stratified low-nutrient water not common in the water column nor in recent or late quaternary sediments of the Portuguese and northwest African margins (Abrantes, 1991a, 1991b; Nave et al., 2003; Romero et al., 2008). However, in the Gulf of California, C. asteromphalus forms large blooms during the fall that sink when the thermocline breaks down (Round, 1968; Kemp, 1995; Kemp et al., 2006). The species has also been described in Peru sediments where Chaetoceros spores are less abundant (Schuette and Schrader, 1981; Fleury 2015).

Although the high abundances of Chaetoceros resting spores and $T$. nitzschioides suggest oceanographic conditions favorable to increased primary productivity from the MIS 26/25 transition to the interglacial period of MIS 25, the presence of C. asteromphalus implies incursions of open-ocean water into the 
southern Portuguese coast and low-wind conditions during the interglacial period of MIS 25.

\section{Acknowledgments}

The samples for this study were provided by the Integrated Ocean Drilling Program (2003-2013). The study funded by the Fundação para a Ciência e a Tecnologia (FCT) project MOWCADYN (PTDC/MARPRO/3761/2012). The authors acknowledge Cremilde Monteiro and Daniel Cruz for their help with laboratory work. A. Voelker, furthermore, acknowledges her Investigador FCT grant (IF/01500/ 2014). We thank Catherine Stickley for her constructive review.

\section{References}

Abrantes, F., 1988. Diatom assemblages as upwelling indicators in surface sediments off Portugal. Marine Geology, 85(1):15-39. http://dx.doi.org/10.1016/00253227(88)90082-5

Abrantes, F., 1991a. Increased upwelling off Portugal during the last glaciation: diatom evidence. Marine Micropaleontology, 17(3-4):285-310. http://dx.doi.org/ 10.1016/0377-8398(91)90017-Z

Abrantes, F., and Moita, M.T., 1999. Water column and recent sediment data on diatoms and coccolithophorids, off Portugal, confirm sediment record of upwelling events. Oceanologica Acta, 22(3):319-336. http://dx.doi.org/10.1016/S0399-1784(99)80055-3

Abrantes, F., Gil, I., Lopes, C., and Castro, M., 2005. Quantitative diatom analyses-a faster cleaning procedure. Deep Sea Research Part I: Oceanographic Research Papers, 52(1):189-198. http://dx.doi.org/10.1016/ j.dsr.2004.05.012

Abrantes, F.F., 1991b. Variability of upwelling off NW Africa during the latest Quaternary: diatom evidence. Paleoceanography, 6(4):431-460. http://dx.doi.org/ 10.1029/91PA00049

Carmelo, R.T., 1996. Identifying Marine Diatoms and Dinoflagellates. With contributions by G.R. Hasle, E.E. Syvertsen, K.A. Steidinger, and K. Tangen: Trondheim, Norway (Academic Press, Inc.). http://www.sciencedirect.com/science/book/9780126930153

Criado-Aldeanueva, F., García-Lafuente, J., Vargas, J.M., Del Río, J., Vázquez, A., Reul, A., and Sánchez, A., 2006. Distribution and circulation of water masses in the Gulf of Cadiz from in situ observations. Deep Sea Research Part II: Topical Studies in Oceanography, 53(11-13):1144-1160. http://dx.doi.org/10.1016/j.dsr2.2006.04.012

de Mendiola, B.R., 1981. Seasonal phytoplankton distribution along the Peruvian Coast. In Richards, F.A. (Ed.), Coastal and Estuarine Sciences (Volume 1): Coastal Upwelling: Washington, DC (American Geophysical Union). http://onlinelibrary.wiley.com/doi/10.1029/ CO001p0348/summary
Dugdale, R.C., and Wilkerson, F.P., 1998. Silicate regulation of new production in the equatorial Pacific upwelling. Nature, 391(6664):270-273. http://dx.doi.org/ 10.1038/34630

Expedition 339 Scientists, 2013. Site U1387. In Stow, D.A.V., Hernández-Molina, F.J., Alvarez Zarikian, C.A., and the Expedition 339 Scientists, Proceedings of the Integrated Ocean Drilling Program, 339: Tokyo (Integrated Ocean Drilling Program Management International, Inc.). http://dx.doi.org/10.2204/ iodp.proc.339.105.2013

Fatela, F., and Taborda, R., 2002. Confidence limits of species proportions in microfossil assemblages. Marine Micropaleontology, 45(2):169-174. http://dx.doi.org/ 10.1016/S0377-8398(02)00021-X

Fleury, S., 2015. Laminations sédimentaires et variabilité climatique et océanographique haute-fréquence sur la marge péruvienne [Ph.D. thesis]. Université de Bordeaux, France. http://www.theses.fr/2015BORD0068/ document

Hasle, G.R., 1959. A quantitative study of phytoplankton from the equatorial Pacific. Deep-Sea Research, 6:38-59. http://dx.doi.org/10.1016/0146-6313(59)90055-3

Hasle, G.R., 1977. Distribution features of some marine planktonic diatoms. In Dunbar, M.J. (Ed.), Polar Oceans: Proceedings of the May 1974 Polar Oceans Conference: Calgary, Alberta (Canada) (Arctic Institute of North America), 375-498.

Hustedt, F., 1964. Die Kieselalgen Deutschlands, Österreichs und der Schweiz. Mit Berücksichtigung der übrigen Länder Europas sowie der angrenzenden Meeresbebiete. In Rabenhorsts, D.L. (Ed.), Kryptogamenflora von Deutschland, Österreich und der Schweiz: Liepzig, Germany (Akademische Verlagsgesellschaft).

Kemp, A.E.S., 1995. Laminated sediments from coastal and open ocean upwelling zones: what variability would they record? In Summerhayes, C.P., Emeis, K.-C., Angel, M.V., Smith, R.L., and Zeitzschel, B. (Eds.), Upwelling in the Ocean: Modern Processes and Ancient Records. Dahlem Workshop Report, ES18:239-257.

Kemp, A.E.S., Pearce, R.B., Grigorov, I., Rance, J., Lange, C.B., Quilty, P., and Salter, I., 2006. Production of giant marine diatoms and their export at oceanic frontal zones: implications for Si and C flux from stratified oceans. Global Biogeochemical Cycles, 20(4):GB4S04. http://dx.doi.org/10.1029/2006GB002698

Moita, T., 2001. Estrutura, variabilidade e dinâmica do fitoplâncton na costa de Portugal continental [Ph.D. thesis]. University of Lisbon, Spain. http://hdl.handle.net/10261/131531

Navarro, G., and Ruiz, J., 2006. Spatial and temporal variability of phytoplankton in the Gulf of Cádiz through remote sensing images. Deep Sea Research Part II: Topical Studies in Oceanography, 53(11-13):1241-1260. http:// dx.doi.org/10.1016/j.dsr2.2006.04.014

Nave, S., Salgueiro, E., and Abrantes, F., 2003. Siliceous sedimentary record of the last $280 \mathrm{kyr}$ in the Canary Basin (NW Africa). Marine Geology, 196(1-2):21-35. http:// dx.doi.org/10.1016/S0025-3227(03)00045-8 
Peliz, A., Marchesiello, P., Santos, A.M.P., Dubert, J., TelesMachado, A., Marta-Almeida, M., and Le Cann, B., 2009. Surface circulation in the Gulf of Cadiz: 2. Inflowoutflow coupling and the Gulf of Cadiz slope current. Journal of Geophysical Research: Oceans, 114(C3):C03011. http://dx.doi.org/10.1029/2008jc004771

Relvas, P., and Barton, E.D., 2002. Mesoscale patterns in the Cape São Vicente (Iberian Peninsula) upwelling region. Journal of Geophysical Research: Oceans, 107(C10):1-23. http://dx.doi.org/10.1029/ 2000JC000456

Romero, O.E., Kim, J.-H., and Donner, B., 2008. Submillennial-to-millennial variability of diatom production off Mauritania, NW Africa, during the last glacial cycle. Paleoceanography, 23(3):PA3218. http://dx.doi.org/ 10.1029/2008PA001601

Round, F.E., 1968. The phytoplankton of the Gulf of California, Part II. The distribution of phytoplanktonic diatoms in cores. Journal of Experimental Marine Biology and Ecology, 2(1):64-86. http://dx.doi.org/10.1016/00220981(68)90014-2

Round, F.E., Crawford, M. and Mann, D.G., 2007. The Diatoms: Biology and Morphology of the Genera: Cambridge, UK (Cambridge University Press).

Schrader, H.-J., 1972. Kieselsäure-Skelette in Sedimenten des ibero-marokkanischen Kontinentalrandes und angrenzender Tiefsee-Ebenen. Meteor-Forschungsergebnisse, 8(C):10-36.

Schrader, H.-J., and Gersonde, R., 1978. Diatoms and silicoflagellates. In Zachariasse, W.J., Riedel, W.R., Sanfilippo, A., Schmidt, R.R., Brolsma, M.J., Schrader, H.J., Gersonde, R., Drooger, M.M., and Broekman, J.A. (Eds.),
Micropaleontological counting methods and techniques: an exercise of an eight metres section of the lower Pliocene of Capo Rossello, Sicily. Utrecht Micropaleontology Bulletin, 17:129-176.

Schuette, G., and Schrader, H., 1981. Diatoms in surface sediments: a reflection of coastal upwelling. In Richards, F.A. (Ed.), Coastal and Estuarine Sciences (Volume 1): Coastal Upwelling: Washington, DC (American Geophysical Union), 372-380. http://onlinelibrary.wiley.com/ doi/10.1029/CO001p0372/summary

Smetacek, V., 2000. Oceanography: the giant diatom dump. Nature, 406(6796):574-575. http://dx.doi.org/ $10.1038 / 35020665$

Voelker, A.H.L., Salgueiro, E., Rodrigues, T., JimenezEspejo, F.J., Bahr, A., Alberto, A., Loureiro, I., Padilha, M., Rebotim, A., and Röhl, U., 2015. Mediterranean Outflow and surface water variability off southern Portugal during the early Pleistocene: a snapshot at marine isotope Stages 29 to 34 (1020-1135 ka). Global and Planetary Change, 133:223-237. http://dx.doi.org/10.1016/ j.gloplacha.2015.08.015

Yoder, J.A., Ackleson, S.G., Barber, R.T., Flamant, P., and Balch, W.M., 1994. A line in the sea. Nature, 371(6499):689-692. http://dx.doi.org/10.1038/ $371689 \mathrm{a} 0$

Initial receipt: 28 January 2016

Acceptance: 18 October 2016

Publication: 7 March 2017

MS 339-202 
Figure F1. Northern Gulf of Cadiz with the position of Site U1387 and major currents. Red arrows = Gulf of Cadiz Current (GCC), blue arrows = main pathway of the upper Mediterranean Outflow Water (u-MOW).

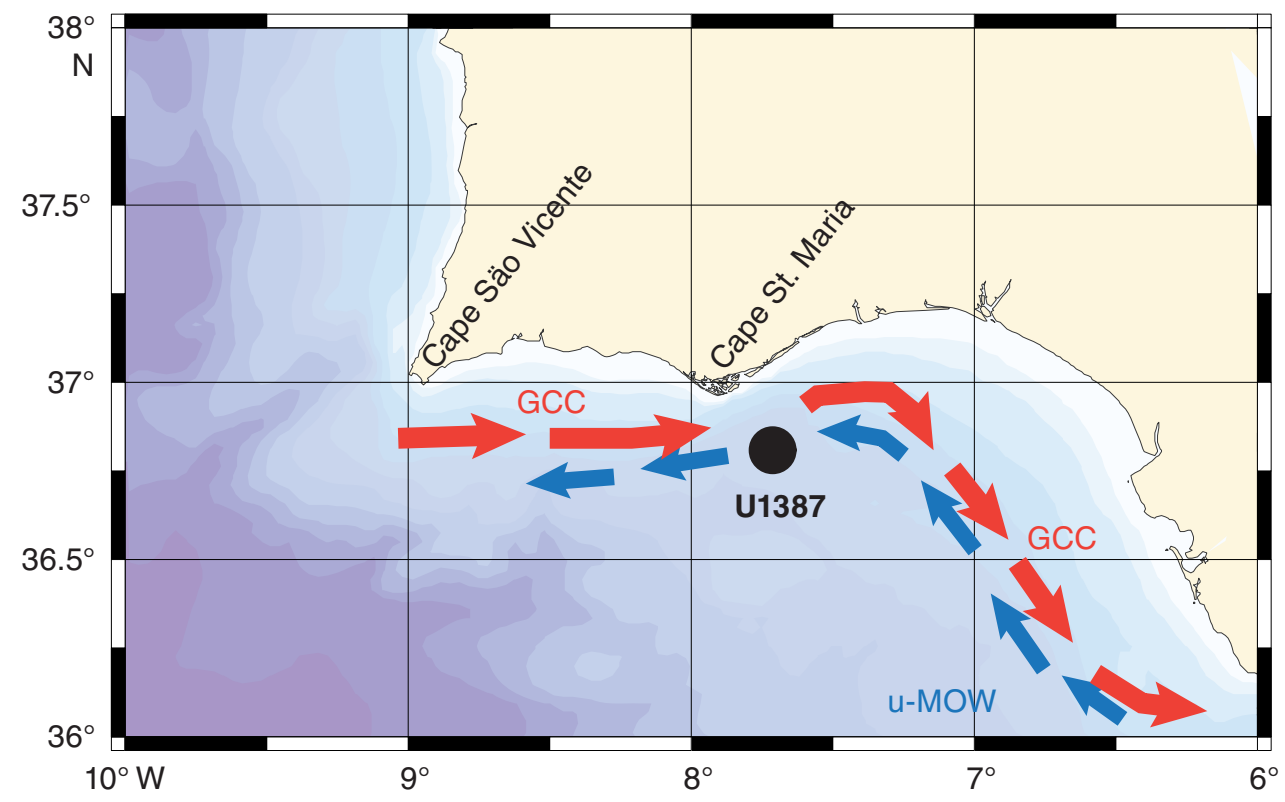


Figure F2. A. $\delta^{18} \mathrm{O}$ record of planktonic foraminifer Globigerina bulloides providing stratigraphic framework. B-D. Diatom and silicoflagellate abundance variations. Dots in B = different levels analyzed. Black crosses in $\mathrm{C}=8$ samples in which the diatom faunal composition was studied. Dashed lines mark marine isotope stage (MIS) boundaries. VPDB = Vienna Peedee belemnite.

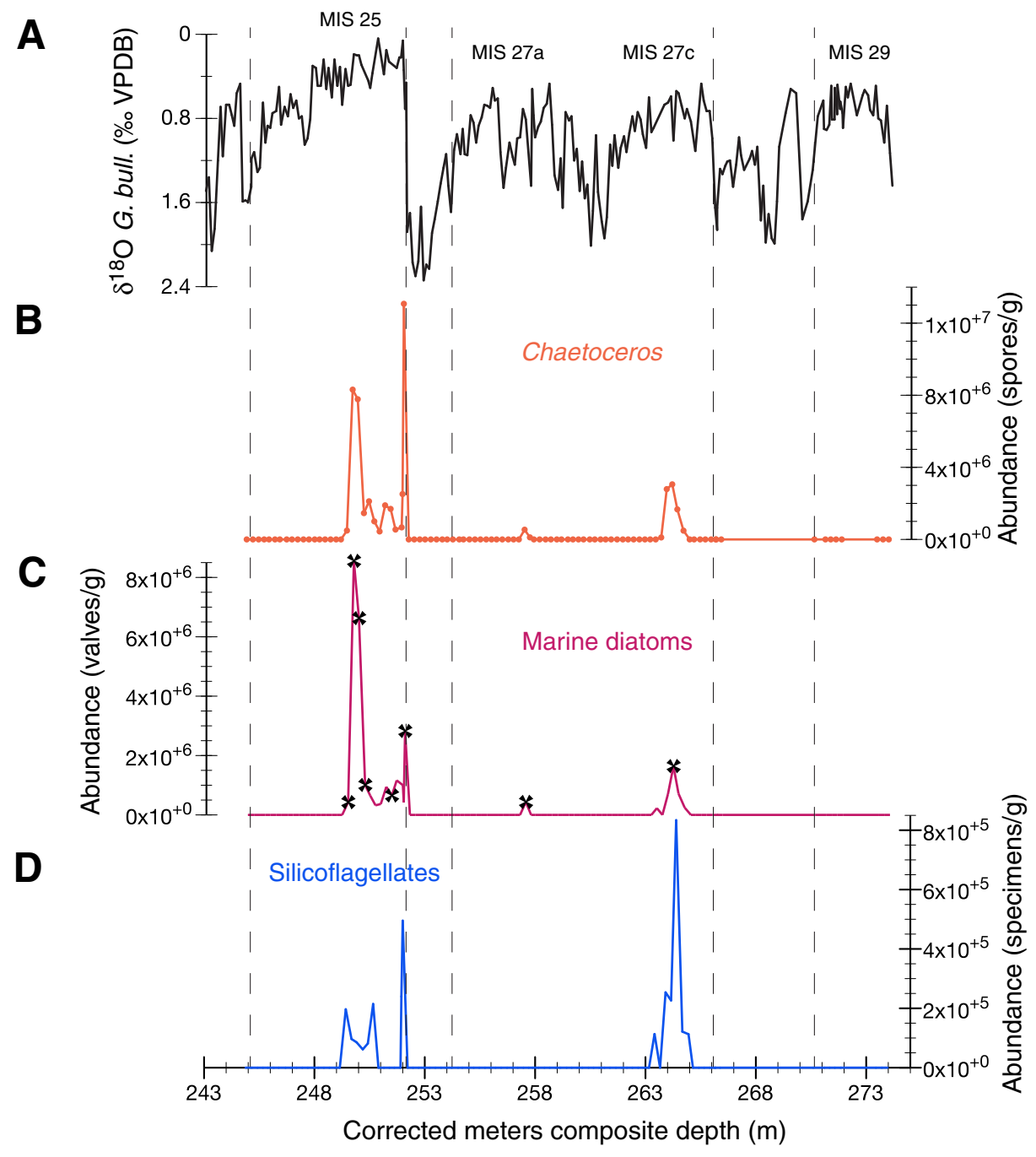


Figure F3. A. Diatom dominant species and ecological groups distribution within the 6 samples containing diatoms. In two samples, the number of diatom specimens encountered in 3 slides was $<95$; therefore, their assemblage composition is not considered. B. Contribution of resistant and weakly silicified diatoms.

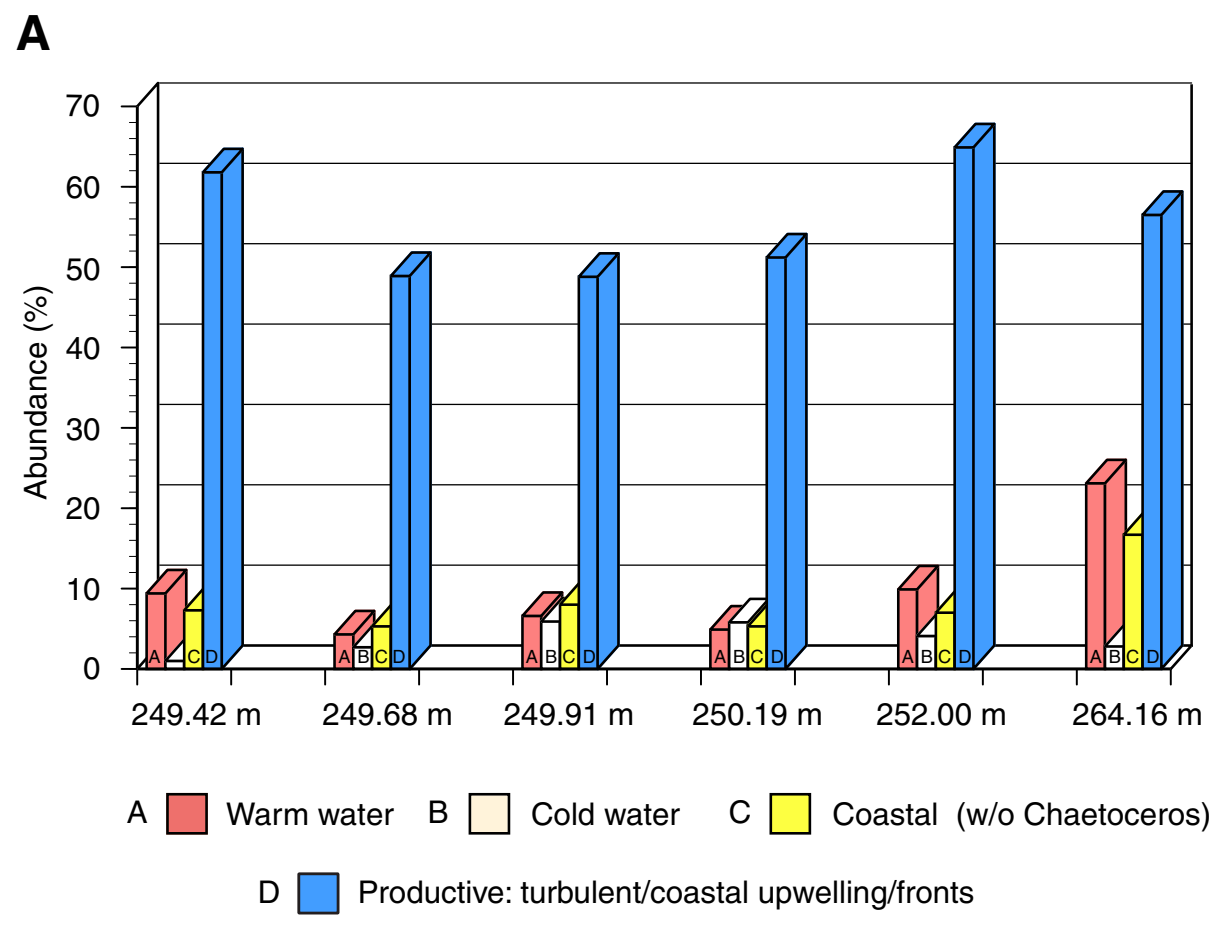

B

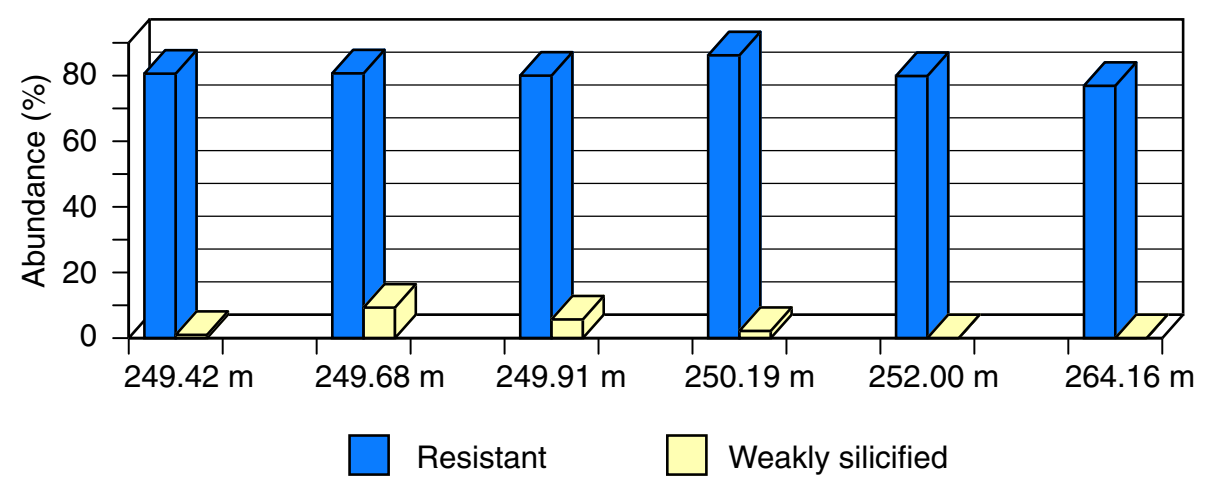


Figure F4. Light microscope views of (A) Coscinodiscus asteromphalus and (B) Coscinodiscus cf. gigas valves collected from the $>125 \mu \mathrm{m}$ fraction (Sample 339-U1387B-24X-5, 124.5-126.5 cm; $249.91 \mathrm{cmcd}$ ).
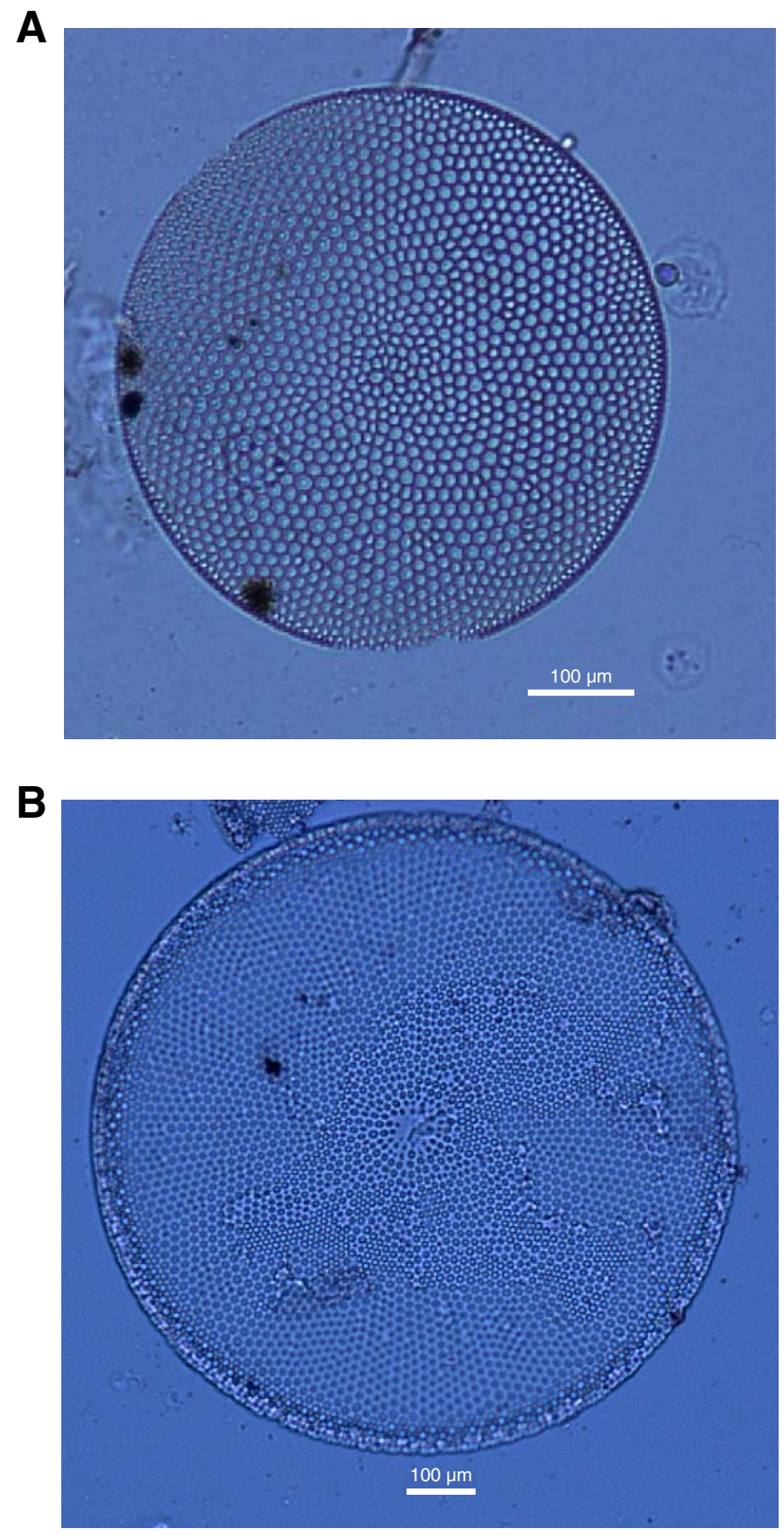
Table T1. Abundances of total Chaetoceros resting spores, marine and freshwater diatoms, and silicoflagellates, Site U1387. (Continued on next page.)

\begin{tabular}{|c|c|c|c|c|c|}
\hline $\begin{array}{l}\text { Hole, core, section, } \\
\text { interval }(\mathrm{cm})\end{array}$ & $\begin{array}{l}\text { Depth } \\
\text { (cmcd) }\end{array}$ & $\begin{array}{l}\text { Chaetoceros } \\
\text { (spores/g) }\end{array}$ & $\begin{array}{l}\text { Marine diatoms } \\
\quad(\text { valves } / \mathrm{g})\end{array}$ & $\begin{array}{c}\text { Freshwater } \\
\text { diatoms } \\
\text { (valves } / g \text { ) }\end{array}$ & $\begin{array}{l}\text { Silicoflagellates } \\
\text { (specimens } / g \text { ) }\end{array}$ \\
\hline \multicolumn{6}{|l|}{$339-$} \\
\hline U1387B-24X-2, 72-74 & 244.88 & 0 & 0 & 0 & 0 \\
\hline U1387B-24X-2, 99.5-101.5 & 245.16 & 0 & 0 & 0 & 0 \\
\hline U1387B-24X-2, 125.5-127.5 & 245.42 & 0 & 0 & 0 & 0 \\
\hline U1387B-24X-3, 1-3 & 245.67 & 0 & 0 & 0 & 0 \\
\hline U1387B-24X-3, 23-25 & 245.89 & 0 & 0 & 0 & 0 \\
\hline U1387B-24X-3, 50-52 & 246.16 & 0 & 0 & 0 & 0 \\
\hline U1387B-24X-3, 72-74 & 246.38 & 0 & 0 & 0 & 0 \\
\hline U1387B-24X-3, 103-105 & 246.69 & 0 & 0 & 0 & 0 \\
\hline U1387B-24X-3, 127-129 & 246.93 & 0 & 0 & 0 & 0 \\
\hline U1387B-24X-4, 3-5 & 247.19 & 0 & 0 & 0 & 0 \\
\hline U1387B-24X-4, 29-31 & 247.45 & 0 & 0 & 0 & 0 \\
\hline U1387B-24X-4, 54-56 & 247.70 & 0 & 0 & 0 & 0 \\
\hline U1387B-24X-4, 79.5-81.5 & 247.96 & 0 & 0 & 0 & 0 \\
\hline U1387B-24X-4, 102-104 & 248.18 & 0 & 0 & 0 & 0 \\
\hline U1387B-24X-4, 127-129 & 248.43 & 0 & 0 & 0 & 0 \\
\hline U1387B-24X-5, 2-4 & 248.68 & 0 & 0 & 0 & 0 \\
\hline U1387B-24X-5, 26.5-28.5 & 248.93 & 0 & 0 & 0 & 0 \\
\hline U1387B-24X-5, 49-51 & 249.15 & 0 & 0 & 0 & 0 \\
\hline U1387B-24X-5, 76-78 & 249.42 & 491,751 & 426,184 & 0 & 196,700 \\
\hline U1387B-24X-5, 102-104 & 249.68 & $8,311,144$ & $8,552,747$ & 0 & 96,641 \\
\hline U1387B-24X-5, 124.5-126.5 & 249.91 & $7,779,137$ & $6,625,090$ & 0 & 85,485 \\
\hline U1387B-24X-6, 3-5 & 250.19 & $1,458,271$ & $1,006,412$ & 0 & 61,617 \\
\hline U1387B-24X-6, 26-28 & 250.42 & $2,116,600$ & 651,262 & 0 & 81,408 \\
\hline U1387B-24X-6, 50-52 & 250.66 & $1,001,496$ & 321,909 & 0 & 214,606 \\
\hline U1387B-24X-6, 74-76 & 250.90 & 441,649 & 368,041 & 0 & 0 \\
\hline U1387B-24X-6, 99-101 & 251.15 & $1,892,097$ & 946,048 & 0 & 0 \\
\hline U1387B-24X-7, 22-24 & 251.40 & $1,694,106$ & 651,579 & 0 & 0 \\
\hline U1387B-24X-7, 43.5-45.5 & 251.62 & 547,652 & $1,163,760$ & 0 & 0 \\
\hline U1387B-24X-CC, 11-13 & 251.90 & 667,428 & $1,001,141$ & 0 & 0 \\
\hline U1387B-24X-CC, 15-17 & 251.94 & $2,517,244$ & 419,541 & 0 & 239,738 \\
\hline U1387B-24X-CC, 21-23 & 252.00 & $13,073,635$ & $2,822,717$ & 0 & 495,213 \\
\hline U1387A-25X-1, 27-29 & 252.22 & 0 & 0 & 0 & 0 \\
\hline U1387A-25X-1, 52-54 & 252.47 & 0 & 0 & 0 & 0 \\
\hline U1387A-25X-1, 77-79 & 252.72 & 0 & 0 & 0 & 0 \\
\hline U1387A-25X-1, 101-103 & 252.96 & 0 & 0 & 0 & 0 \\
\hline U1387A-25X-1, 127-129 & 253.22 & 0 & 0 & 0 & 0 \\
\hline U1387A-25X-2, 3-5 & 253.48 & 0 & 0 & 0 & 0 \\
\hline U1387A-25X-2, 29-31 & 253.74 & 0 & 0 & 0 & 0 \\
\hline U1387A-25X-2, 51-53 & 253.96 & 0 & 0 & 0 & 0 \\
\hline U1387A-25X-2, 77-79 & 254.22 & 0 & 0 & 0 & 0 \\
\hline U1387A-25X-2, 106-108 & 254.51 & 0 & 0 & 0 & 0 \\
\hline U1387A-25X-2, 125-127 & 254.70 & 0 & 0 & 0 & 0 \\
\hline U1387A-25X-3, 2-4 & 254.97 & 0 & 0 & 0 & 0 \\
\hline U1387A-25X-3, 27-29 & 255.22 & 0 & 0 & 0 & 0 \\
\hline U1387A-25X-3, 52-54 & 255.47 & 0 & 0 & 0 & 0 \\
\hline U1387A-25X-3, 77.5-79.5 & 255.73 & 0 & 0 & 0 & 0 \\
\hline U1387A-25X-3, 102-104 & 255.97 & 0 & 0 & 0 & 0 \\
\hline U1387A-25X-3, 125-127 & 256.20 & 0 & 0 & 0 & 0 \\
\hline U1387A-25X-4, 1-3 & 256.46 & 0 & 0 & 0 & 0 \\
\hline U1387A-25X-4, 28-30 & 256.73 & 0 & 0 & 0 & 0 \\
\hline U1387A-25X-4, 52-54 & 256.97 & 0 & 0 & 0 & 0 \\
\hline U1387A-25X-4, 76-78 & 257.21 & 0 & 0 & 0 & 0 \\
\hline U1387A-25X-4, 102-104 & 257.47 & 540,552 & 432,442 & 0 & 0 \\
\hline U1387A-25X-4, 126-128 & 257.71 & 113,659 & 0 & 0 & 0 \\
\hline U1387B-25X-1, 50-52 & 257.89 & 0 & 0 & 0 & 0 \\
\hline U1387B-25X-1, 76-78 & 258.15 & 0 & 0 & 0 & 0 \\
\hline U1387B-25X-1, 103-105 & 258.42 & 0 & 0 & 0 & 0 \\
\hline U1387B-25X-1, 127-129 & 258.66 & 0 & 0 & 0 & 0 \\
\hline U1387B-25X-2, 4-6 & 258.93 & 0 & 0 & 0 & 0 \\
\hline U1387B-25X-2, 24.5-26.5 & 259.14 & 0 & 0 & 0 & 0 \\
\hline U1387B-25X-2, 53.5-55.5 & 259.43 & 0 & 0 & 0 & 0 \\
\hline U1387B-25X-2, 77-79 & 259.66 & 0 & 0 & 0 & 0 \\
\hline U1387B-25X-2, 102-104 & 259.91 & 0 & 0 & 0 & 0 \\
\hline U1387B-25X-2, 125-127 & 260.14 & 0 & 0 & 0 & 0 \\
\hline U1387B-25X-3, 3-5 & 260.42 & 0 & 0 & 0 & 0 \\
\hline U1387B-25X-3, 25.5-27.5 & 260.65 & 0 & 0 & 0 & 0 \\
\hline
\end{tabular}


Table T1 (continued).

\begin{tabular}{|c|c|c|c|c|c|}
\hline $\begin{array}{l}\text { Hole, core, section, } \\
\text { interval }(\mathrm{cm})\end{array}$ & $\begin{array}{l}\text { Depth } \\
\text { (cmcd) }\end{array}$ & $\begin{array}{l}\text { Chaetoceros } \\
\text { (spores/g) }\end{array}$ & $\begin{array}{l}\text { Marine diatoms } \\
\quad \text { (valves/g) }\end{array}$ & $\begin{array}{c}\text { Freshwater } \\
\text { diatoms } \\
\text { (valves } / g \text { ) }\end{array}$ & $\begin{array}{l}\text { Silicoflagellates } \\
\text { (specimens/g) }\end{array}$ \\
\hline U1387B-25X-3, 52-54 & 260.91 & 0 & 0 & 0 & 0 \\
\hline U1387B-25X-3, 75-77 & 261.14 & 0 & 0 & 0 & 0 \\
\hline U1387B-25X-3, 100-102 & 261.39 & 0 & 0 & 0 & 0 \\
\hline U1387B-25X-3, 127-129 & 261.66 & 0 & 0 & 0 & 0 \\
\hline U1387B-25X-4, 3-5 & 261.92 & 0 & 0 & 0 & 0 \\
\hline U1387B-25X-4, 27-29 & 262.16 & 0 & 0 & 0 & 0 \\
\hline U1387B-25X-4, 52-54 & 262.41 & 0 & 0 & 0 & 0 \\
\hline U1387B-25X-4, 78-80 & 262.67 & 0 & 0 & 0 & 0 \\
\hline U1387B-25X-4, 103-105 & 262.92 & 0 & 0 & 0 & 0 \\
\hline U1387B-25X-4, 127-129 & 263.16 & 0 & 0 & 0 & 0 \\
\hline U1387B-25X-5, 2-4 & 263.41 & 0 & 226,484 & 0 & 113,242 \\
\hline U1387B-25X-5, 27-29 & 263.66 & 109,110 & 0 & 0 & 0 \\
\hline U1387B-25X-5, 52-54 & 263.91 & $2,791,181$ & 697,795 & 0 & 253,744 \\
\hline U1387B-25X-5, 77-79 & 264.16 & $3,056,211$ & $1,641,299$ & 0 & 226,386 \\
\hline U1387B-25X-5, 100-102 & 264.39 & $1,667,350$ & 714,579 & 0 & 833,675 \\
\hline U1387B-25X-5, 127.5-129.5 & 264.67 & 485,951 & 242,976 & 0 & 121,488 \\
\hline U1387B-25X-6, 5.5-7.5 & 264.95 & 0 & 0 & 0 & 112,758 \\
\hline U1387B-25X-6, 26-28 & 265.15 & 0 & 0 & 0 & 0 \\
\hline U1387B-25X-6, 53-55 & 265.42 & 0 & 0 & 0 & 0 \\
\hline U1387B-25X-6, 77-79 & 265.66 & 0 & 0 & 0 & 0 \\
\hline U1387B-25X-6, 103-105 & 265.92 & 0 & 0 & 0 & 0 \\
\hline U1387B-25X-6, 125-127 & 266.14 & 0 & 0 & 0 & 0 \\
\hline U1387A-26X-1, 5-7 & 266.14 & 0 & 0 & 0 & 0 \\
\hline U1387A-26X-1, 29-31 & 266.38 & 0 & 0 & 0 & 0 \\
\hline U1387A-26X-4, 1-3 & 270.60 & 0 & 0 & 0 & 0 \\
\hline U1387A-26X-4, 51-53 & 271.10 & 0 & 0 & 0 & 0 \\
\hline U1387A-26X-4, 75-77 & 271.34 & 0 & 0 & 0 & 0 \\
\hline U1387A-26X-4, 99-101 & 271.58 & 0 & 0 & 0 & 0 \\
\hline U1387A-26X-4, 125-127 & 271.84 & 0 & 0 & 0 & 0 \\
\hline U1387B-26X-2, 100-102 & 273.44 & 0 & 0 & 0 & 0 \\
\hline U1387B-26X-2, 126.5-128.5 & 273.71 & 0 & 0 & 0 & 0 \\
\hline U1387B-26X-3, 3-5 & 273.97 & 0 & 0 & 0 & 0 \\
\hline
\end{tabular}

Table T2. Identified diatom taxa and ecologies in studied samples of Site U1387.

\begin{tabular}{|c|c|}
\hline Taxa & Ecology \\
\hline Actinocyclus ochotensis A.P. Jousé & Pelagic, warm water \\
\hline Actinocyclus senarius (Ehr.) Ehrenberg & Neritic, cosmopolitan \\
\hline Bacteriastrum hyalinum Lauder & Benthic \\
\hline Biddulphia spp. S.F. Gray & Benthic \\
\hline Chaetoceros spp. Ehrenberg & Neritic, productive turbulent waters \\
\hline Campylodiscus spp. Ehrenberg ex Kützing & Benthic \\
\hline Coscinodiscus spp. Ehrenberg & Pelagic, warm water \\
\hline Coscinodiscus asteromphalus Ehrenberg* & Pelagic, warm water \\
\hline Coscinodiscus apiculatus Ehrenberg* & Pelagic, warm water \\
\hline Coscinodiscus cf. Coscinodiscus gigas Ehrenberg* & Pelagic, warm water \\
\hline Denticula spp. Kützing & Pelagic \\
\hline Diploneis bombus Ehrenberg & Benthic \\
\hline Eunotia spp. Ehrenberg & Freshwater \\
\hline \multicolumn{2}{|l|}{ Navicula spp. Bory de Saint-Vincent } \\
\hline Navicula marina Ralfs in Pritchard & Pelagic, warm water \\
\hline Paralia sulcata (Ehr.) Cleve & Neritic shadow species \\
\hline \multicolumn{2}{|l|}{ Rhizosolenia spp. Ehrenberg } \\
\hline Rhizosolenia bergonii H. Pergallo & Pelagic, warm water \\
\hline Proboscia alata (Brightwell) Sundström & Pelagic, cosmopolitan \\
\hline Proboscia hebetata Bailey & Pelagic, cold water \\
\hline Proboscia styliformis Brightwell & Pelagic, warm water \\
\hline Stephanopyxis turris (Grev.) Ralfs & Neritic \\
\hline $\begin{array}{l}\text { Thalassionema nitzschioides (Grunow) Mereschkowsky } \\
\text { Thalassiosira spp. Cleve }\end{array}$ & Pelagic, cosmopolitan \\
\hline Thalassiosira oestrupii (Ostenfeld) Hasle & Pelagic, warm water \\
\hline Thalassiosira trifulta G. Fryxell in Fryxell and Hasle & Pelagic, cold water \\
\hline Thalassiothrix cf. Thalassiothrix longissima Cleve and Grunow & Pelagic, cosmopolitan \\
\hline
\end{tabular}

* = taxa found only in the $>63 \mu \mathrm{m}$ sediment fraction. 